\title{
The Relationship between Ownership Structure and Dividend Policy in an Emerging Market: A Moroccan Study
}

\author{
Aziz Mossadak, Richard Fontaine, Hanen Khemakhem* \\ School of Management Sciences, University of Quebec in Montreal, Canada
}

Copyright $\mathrm{O} 2016$ by authors, all rights reserved. Authors agree that this article remains permanently open access under the terms of the Creative Commons Attribution License 4.0 International License

\begin{abstract}
The objective of this study is to examine the effect of ownership structure on dividend policy in the context of an emerging market. In the academic literature, covering various economic contexts, research shows contradictory results. Therefore, based on a sample of 146 observations, we analysed the relationship between the ownership structure and the dividend policy in Morocco. The results of our study show a positive and significant relationship between ownership structure and dividend policy; however, one of the ownership structures (institutional ownership) did not show a significant relationship with dividend policy. Our results are surprising as they contradict Aguenaou et al. [1] and Pablo and González [2] who instead find negative relationships. Our results add to the existing literature by providing unique results in an emerging market such as Morocco.
\end{abstract}

Keywords Ownership Structure, Dividend Policy, Emerging Markets

\section{Introduction}

Dividends are the part of corporate earnings distributed to shareholders for their participation in the capital of a corporation. And dividend policy is the process of deciding between retaining profits and disbursing profits to shareholders [3].

Dividend policy has been largely debated in the financial literature over the years $[4,5]$. The central debate is on the different elements that could influence a company's dividend policy choice. Different theories have been developed that help explain a company's behaviour towards a dividend policy: the theory of non-pertinence [4], the «bird in the hand » theory [6,7], and the fiscal advantage theory [8]. Jensen [9] and Shleifer and Vishny [10] also explain dividend policy in the context of agency theory based on various conflicts within the organization.

For example, Shleifer and Vishny [10] claim that large shareholders personally benefit from corporations by obtaining a limited distribution of dividends. According to the two authors, this is a form of expropriation of minority shareholders. LaPorta et al. [11] explain this expropriation by highlighting that companies that are equipped with judicial protection of shareholders disperse more dividends. In emerging marketing, this shareholder protection is not as efficient as in developed countries ${ }^{1}$. However, Aivazian and Booth [12] conclude that the level of dividends is higher in emerging markets than in developed countries. This contradiction motivates the question as to what are the factors that could influence the dividend policy in emerging markets.

In the financial markets, the shareholder of companies is quite varied and each shareholder could have different interests concerning their participation in the corporation's capital. According to Allen et al. [13], institutional investors (pension funds, insurance, and hedge funds) prefer receiving higher dividends. Minority shareholders, having short-term objectives, also prefer higher dividends [14].

Conversely, companies with high levels of ownership concentration have a tendency to distribute fewer dividends [15]. Shleifer and Vishny [16] find that majority shareholders prefer generating earnings and reducing dividends. This divergence of interests highlights the problem as to how the concentration of shareholders influences the corporation's dividend policy.

Therefore the objective of this study is to analyze the relationship between the ownership structure and dividend policy of companies listed on the Casablanca stock exchange. More precisely, in this study we look at the role of the ownership structure as an explanatory factor of the level of dividends in the context of emerging markets such as Morocco.

Morocco is part of the emerging markets similar to certain Asian countries (Indonesia and Jordan), African countries (Tunisia and Egypt), and Latin American countries (Argentina and Mexico). The stock market of Casablanca (Morocco) experienced vitality during the 1990s up to the year 2000 during the privatization program in Morocco and during the

\footnotetext{
${ }^{1}$ More the countries are developed, more the shareholder's protection is high (Armour et al. [17]).
} 
promotion of companies to list on the stock exchange. This created the emergence of a new shareholder base composed of institutional investors, foreign investors, and family companies listed on the financial markets with the objective of obtaining new sources of financing ${ }^{2}$.

The results of our study show that the higher the ownership concentration is in Morocco, the higher is the dividend payout. In addition, we found that the higher the percentage of foreign ownership is in Moroccan companies, the higher the dividend distribution. We did not find a significant relationship between institutional ownership and dividend distribution.

Our study is important as it helps clarify contradictory results in the literature. A similar study, (Aguenaou et al. [1]), conducted in Morocco, found a negative relationship between ownership concentration and dividend distribution. However, we argue that the fact that these authors studied companies during the period covering 2004-2010, which includes the period of the sub-prime financial crisis, the results could contain important biases. Moreover, these same authors included financial companies, which we excluded. This is important, since financial companies are typically removed from similar studies due to specific regulations that could affect ownership and dividend regulations.

This article is structured as follows: We present our theoretical basis and a revue of the pertinent literature, which leads to our hypotheses. We then present our methodology, the results of our study, followed by a conclusion and discussion.

\section{Theoretical Basis}

Various theoretical views help explain the motivation behind a corporation's dividend policy. One of these theoretical views is signaling theory. For example, dividend policy is considered as the arbitrage between the retention of earnings and the distributions of liquidity to shareholders [3]. In other words, dividend policy is the determination of the part of net profit that is distributed to shareholders. Therefore in situations of scarce financial information, outside shareholders consider the company's dividend policy as the only indicator of corporate performance. Consequently, an increase in dividend payments is reflected by an increase in the corporation's share price. Aware of the situation, corporate managers use dividends as a signal of the perspectives of a growth in earnings [20].

Another wide held theoretical explanation for a dividend policy is agency theory. According to Rozeff [21], dividend policy is influenced by agency theory that predicts a conflict between management and shareholders. As a result of this agency conflict, Jensen [9] argues that the main advantage of dividends for shareholders is to reduce the liquidity available

2 "Introduction to the Casablanca stock exchange: trends, determinants and technical results" minister of finance and privatisation, 2009" (direct translation of the original document titled in French as follows: " Introductions à la Bourse de Casablanca: tendencies, determinants et résultats techniques » ministère des Finances et de la Privatisation, 2009. for management's discretionary expenses, consequently imposing a more financial rigor on management, reducing the agency costs.

Agency theory also helps explain the relationship between dividend policy and higher concentrated ownership. Shleifer and Vishny [10] suggest that a higher level of ownership leads to a better supervision of management. This contributes to better financial results and therefore provides higher dividends to minority shareholders, as well as, to larger shareholders. These higher dividends are considered monitoring costs that higher level owners require to recover their costs for monitoring management. Likewise, Easterbrook [23] indicates that majority shareholders require a high level of dividends for two reasons: (1) reduce agency conflict and (2) recover monitoring costs.

In the same way as concentrated ownership, institutional shareholders prefer investing in companies that distribute more dividends (Allen et al. [13]). These types of investors, with their resources, influence the management of the company, primarily in respect to dividend policy. These are sophisticated investors that seek to reduce agency costs by the means of a higher level of dividends: the dividend policy is considered a mechanism of control [1].

\section{Literature Review and Hypotheses}

Most of the empirical research on dividend policy looks at the determining factors that influence a corporation's distribution of earnings to shareholders, among which ownership structure is cited as a determinant $[2,18]$. In this literature, the ownership of property is defined by a group of characteristics related to the nature and identity of those that own the capital of the company $[18,1]$. The research attempts to establish relationships between the group of characteristics and the company's dividend policy $[19,2]$ as we explain further in this section.

\subsection{The Relationship between Dividend Policy and Ownership Structure}

When looking at the relationship between the ownership structure and the dividend policy, ownership structure includes the level of ownership concentration as well as the identity and nature of shareholders. From the existing literature, we present the relationships of corporate dividend policy with these different components of ownership structure as presented below.

\subsubsection{Dividend policy and the level of ownership concentration}

Pablo and González [2] conducted research on 1664 Latin American companies in five countries: Bresil, Perou, Argentina, Chili and Colombia. The authors were interested in only one aspect of the ownership structure, the level of ownership concentration, which was measured by the 
Herfindahl index (the squared sum of the percentages of ownership of shareholders); the dividend policy was defined by the dividend rate. The results obtained indicate a negative relationship between the concentration of property and the distribution of dividends.

However, research in other emerging markets show different results. Norhasniza et al. [22] conducted research in Malaysia with a sample of 100 listed companies on the «Bursa Malaysie ». The authors demonstrated a positive relationship between the level of ownership and dividend policy. These researchers explain their results confirming that the dividend payment is a method to reduce the agency conflict, as mentioned above in our theoretical basis section.

Therefore, our first hypothesis is:

H1: There is a positive relationship between the ownership concentration and the dividend level.

\subsubsection{Dividend policy and institutional ownership}

As an example of the impact of institutional investors on dividend policy, Jain [14] analyzed the ownership structure and dividend policy of a sample of 287 listed companies on the Thailand stock exchange (SET). The author defined the ownership structure by the concentration of ownership, institutional ownership (local and foreign), and individual ownership (local and foreign). The results indicate a positive relationship with ownership concentration and dividend policy, in the presence of an institutional shareholder. However, the relationship is negative between the ownership concentration and dividend policy in the presence of an individual shareholder; and the impact of foreign ownership is not demonstrated.

Consistent with these findings, Al-Gharaibeh et al. [19] studied the impact of ownership structure on the dividend policy of 35 listed companies on the Amman stock exchange. The authors concluded that the institutional ownership is positively related to the dividend policy.

Other research shows opposing results. Aguenaou et al. [1] $]^{3}$ analyzed the ownership structure of companies listed on the Casablanca stock exchange (Morocco). The results obtained show a negative relationship between institutional ownership and dividend policy.

Consistent with our theoretical basis, presented above, institutional investors, contrary to minority shareholders, have an influence over the management of the company, due to their expertise and due to the importance of their investment in the company [24]. This influence over management affects a company's dividend policy. According to Aguenaou et al. [1], institutional investors exert pressure so they can receive a high level of dividends in order to reduce agency costs; this is also confirmed by Allen et al. [13] who confirm that institutional investors benefit from a higher dividend level. Based on these results we establish our second hypothesis:

$\mathrm{H} 2$ : There is a positive relationship between institutional

3 The context of our study is similar to Aguenaou et al. [1]; however, the choice of sample and the measure of the variables are different. ownership and the dividend level.

\subsubsection{Dividend policy and foreign ownership}

Foreign shareholders can also influence dividend policy according to Cook and Jeon [27]. The results of these researchers show that the presence of foreign shareholders is related to a high payment of dividends. They argue that foreign investors are active investors who look to reduce agency problems, as they require a high level of dividends.

Despite these results, other research did not find a relationship between foreign shareholders and dividend policy. Manos [28] studied the ownership structure and its relationship on dividend policy in 661 non-financial companies listed on the Bombay Stock Exchange in India. The author used the cost minimization model of Rozeff [21]. This model stipulates that the target value of the dividend is the level that permits to minimize the cost of external financing and at the same time minimize agency costs [28]. The author modeled the structure of ownership according to four variables: managerial ownership, institutional ownership, foreign ownership and dispersed ownership. The results indicate a positive and significant relationship for all the variables, with the exception of foreign ownership.

Foreign ownership is a characteristic of ownership structure that was analysed by Cook and Jeon [27]. These two authors confirm that foreign investors who worry about their investments consequently look to reduce their agency costs by reclaiming a high level of dividends. Norhasaniza et al. [22] did not find a significant relationship between foreign ownership and dividend policy; however, Cook and Jeon [27] did establish a positive relationship; therefore, our third hypothesis is.

H3: There is a positive relationship between foreign ownership and the dividend level.

To summarize our hypotheses, the relationship between ownership structure and dividend policy, as we presented above, is theoretically justified and empirically demonstrated in several empirical studies. Drawing on these conclusions we established three hypotheses to test in our study. The first is related to the level of ownership; it allows us to understand if the presence of a concentrated shareholder base influences a company's dividend policy. The second and third hypotheses relate to the influence of the shareholder's nature on dividend policy.

\section{Methodology}

This methodology section includes the choice of our sample, the definition of variables, the model of analysis, as well as the statistical methods that we applied.

\subsection{Sample and Data}

Our study is conducted in an emerging economy. We analyze the relationships that exist between the structure of 
ownership and the dividend policy in companies listed on the Casablanca stock exchange.

Our sample is comprised of companies listed on the Casablanca exchange between the years 2011 and 2013. Of the 74 companies initially listed, we included all the disclosed industries with the exception of companies in the financial sector due to their particularity in regards to the structure of capital and dividend policy. The final sample is 53 companies. We also excluded from our sample the years in which the companies declared losses. The final number of observations obtained is 143 . This number represents almost $90 \%$ of the possible observations from 2011 to $2013^{4}$. Table 1 shows the spread of the observations per year.

Table 1. Sample of companies per year

\begin{tabular}{|c|c|c|c|c|}
\hline Year & 2011 & 2012 & 2013 & Total \\
\hline Number of observations & 48 & 46 & 49 & 143 \\
\hline
\end{tabular}

Many studies in the literature were conducted using a sample comparable to ours. Indeed, Mancinelli and Ozkan [29] use a sample of 139 observations and Norhasniza et al. [22] use a sample of 100 observations.

Our data were collected from the information available on the website of the Casablanca stock exchange, principally the annual rapports, press releases, as well as the financial statements.

In our sample, $52 \%$ of the companies' shareholders are institutional investors: they have ownership in social capital that exceeds $50 \%$. The foreign investors that possess $5 \%$ or more of the equity account for $37 \%$ of our sample. This shows that institutional and foreign investors are important types of shareholders at the Casablanca stock exchange.

\subsection{Research Model}

To test the relationship between the structure of property and the dividend policy, we used the following model:

$$
\begin{aligned}
\text { DivPoly }= & \beta_{0}+\beta_{1} \text { Cons_Own }+\beta_{2} \text { PorpInst }+\beta_{3} \text { Frn_Own }+ \\
& +\beta_{4} \text { Dept }+\beta_{5} \text { Size }+\beta_{6} \text { ROE }+\varepsilon_{1}
\end{aligned}
$$

With:

DivPoly: dividend policy measured by the dividend/earnings ratio,

Cons_Own: concentration of ownership measured by the Herfindahl indice,

Ins_Own: institutional ownership measured by the percentage of institutional ownership divided by total equity,

Frn_Own: foreign ownership, measured by the percentage of foreign ownership divided by total equity,

Size: size of company measured with the Log the of sales (revenues),

Debt: debt ratio measured by total debt/ total assets.

4 The Moroccan stock market is an emerging and very small financial marke with 74 listed companies from 2011 to 2014. After excluding financial companies, this number drops to 53 companies. Out of 159 possible observations (53 firms over a period of three years), we have 143 firm-year observations, which represents $89.97 \%$ of all possible observations.
ROE: return on equity ratio

$\varepsilon_{1}$ : error coefficient.

\subsubsection{Definition of variables}

\section{- Dependent variable: Dividend policy}

In the study of Pablo and Gonzales [2], the dividend policy is measured by the dividend rate (the percentage of dividend payout). We use this ratio for the definition of the dividend policy (DivPoly), since it accurately reflects the dividend policy. In fact, this permits arbitrage between the retention of earnings and the distribution of liquidity to shareholders [3].

\section{- Independent variables}

The independent variables represent the ownership structure. Three variables were retained to model the ownership structure: ownership concentration, institutional ownership and foreign ownership.

The ownership concentration indicates the level of ownership of the principle shareholder. In the present research, we measure the concentration by the Herfindahl index. It is one of the measures the most used in the literature [2,25]. In the research in governance, the index is used to calculate the level of concentration of ownership of companies [26]. Often a logarithmic transformation is applied to the obtained value. The index is equal to the squared total percentages of shareholder ownership 5 .

The institutional ownership is measured by the percentage of equity retention, by pension funds, insurance, and securities commissions. Cook and Jeon $[27]^{6}$ use the same measure.

The foreign ownership is measured by the percentage of foreign ownership divided by total equity. We use the same measure as Cook and Jeon [27].

\section{- Control variables}

Based on the existing literature, three control variables were retained:

ROE: the ratio of return on equity, an indicator of profitability is measured by the ratio earnings/equity. Fama and French [32] established a positive relationship between the profitability of the company and dividend payments.

Size: the size of the company measured by the size by the Log of total sales. This variable was used in many studies such as Harada and Nguyen [25] and Chen and al.[31]. In our research, size is measured by the Log of total sales following the example of Mancinelli and Ozkan [29].

Debt ratio: this variable is used by Pablo and Gonzalez [2] and Mancinelli and Ozkan [29] and it is measured by the total debt divided by total assets.

5 Example Herfindahl index calculation: shareholder ownership A $45 \%$, B $30 \%$, C $15 \%$ and D $10 \%$, Herfindahl index $=0.45^{2}+0.30^{2}+0.15^{2}+0.10^{2}=$ 0.325

6 The intuitional ownership variable takes on a value of « 1 » when the ownership is $5 \%$ and $" 0 »$ otherwise [33]. This measure permits to distinguish from the research of Aguenaou et al. [1] who also studied the Moroccan context. 


\section{Results}

The results of ownership concentration presented in table 2 show a positive and significant relationship between the level of ownership concentration and the level of the distribution of dividends. The relationship is significant at the 5\% level. We conclude that ownership concentration has a positive impact on the level of dividends, which supports hypothesis $\mathrm{H}_{1}$. These results are consistent with the conclusions by Shleifer and Vishny [10] and Easterbrook [23] who argue that in a situation of ownership the principle shareholders require a high level of dividends in order to reduce agency costs: reduce the available liquidity to management who could use the liquidity for discretionary expenses.

The results of the regression did not show a significant relationship between the dividend policy and institutional ownership. Therefore, we cannot establish a relationship between dividend policy and institutional ownership; hypothesis $\mathrm{H}_{2}$, in this case, is not supported. In respect to foreign ownership, the results indicate a positive and significant relationship between the level of the presence of foreign shareholders and the level of dividend distribution. The relationship between the two variables is significant at the $5 \%$ level. In other words, the more the level of foreign ownership increases, the more the level of distribution of dividends increases. Hypothesis $\mathrm{H}_{3}$ is therefore supported. This result is consistent with Cook and Jeon [27] that also found a positive relationship. This concludes that foreign investors worrying for their investments seek to reduce the agency costs by reclaiming a high level of dividends.

Finally, the Fischer test indicates significant results. In addition, the adjusted $\mathrm{R}^{2}$ of $72 \%$ shows the power of the model.

Table 2. Regression results

\begin{tabular}{|c|c|c|c|c|}
\hline Variables & Coefficient & $\begin{array}{c}\text { Standard } \\
\text { error }\end{array}$ & $\mathrm{t}$ & p. value \\
\hline Constante & $-16.9798 * *$ & 6.90225 & -2.4600 & 0.01594 \\
\hline Cons_Own & $22.7233 * *$ & 9.37422 & 2.4240 & 0.01750 \\
\hline Ins_Own & -1.79053 & 1.54567 & -1.1584 & 0.24998 \\
\hline Frn_Own & $28.3587 * *$ & 12.3275 & 2.3005 & 0.02390 \\
\hline Size & 0.23158 & 0.22919 & 1.0104 & 0.31519 \\
\hline Debt & $-1.31644 *$ & 0.705588 & -1.8657 & 0.06557 \\
\hline ROE & -0.114625 & 0.262932 & -0.4359 & 0.66399 \\
\hline \multicolumn{2}{|c|}{ Adjusted $\mathrm{R}^{2}$} & \multicolumn{3}{|c|}{0.723918} \\
\hline \multicolumn{2}{|c|}{$\mathrm{F}(58.84)$} & \multicolumn{3}{|c|}{$7.419657 * * *$} \\
\hline \multicolumn{2}{|c|}{ Log of likelihood } & \multicolumn{3}{|c|}{-11.34246} \\
\hline \multicolumn{2}{|c|}{ p. Value (F) } & \multicolumn{3}{|c|}{$1.92 \mathrm{e}-16$} \\
\hline \multicolumn{2}{|c|}{ Durbin-Watson } & \multicolumn{3}{|c|}{2.133907} \\
\hline
\end{tabular}

$* * * \operatorname{sig}$. at $1 \% * * \operatorname{sig}$. at $5 \% * \operatorname{sig}$. at $10 \%$

With:

DivPoly: dividend policy measured by the dividend ration/earnings.

Cons_Own: ownership concentration measured by the
Herfindahl index.

Ins Own: institutional ownership measured by the ownership percentage in respect to equity.

Frn_Own: foreign ownership measured by the percentage of foreign ownership in respect to total equity.

Size: size of the company measured by the LOG of sales.

Debt: debt ratio measured by total debt divided by total assets.

ROE: return on equity.

\section{Conclusion and Discussion}

The objective of this study is to investigate the existence of relationships between the structure of ownership and dividend policy in an emerging market. To achieve our objective, we studied a sample of non-financial companies listed on the Casablanca stock exchange between 2011 and 2013. We used a linear regression model permitting to explain the dividend policy and we used three independent variables to determine the concentration of ownership, foreign ownership and intuitional ownership.

Our results show a positive and significant relationship between ownership concentration and the dividend policy. These results are consistent with the conclusions of several research conducted in the context of emerging markets, notably the study of Norhasniza et al. [22] in Malaysia and of Thanatawee [14] in Thaillande. Our results are also aligned with the opinion of Shleifer and Vishny [10] according to which majority shareholders exert an influence to reduce the resources put to the disposition of directors who could use these resources in projects that favor their self-interests.

However, the main contribution of this study lies in our contradicting results in respect to the study of Aguenaou et al. [1] (also conducted in the Moroccan context). The results of this last study did not demonstrate a significant relationship between ownership concentration and dividend policy; whereas we did. The divergence in the results could be explained by the different methodological approach used by Aguenaou et al. [1] $]^{7}$. Firstly, unlike these authors, we did not include the financial sector in our analysis. This is important because financial companies are subject to their own specific regulations pertaining to ownership structure and dividend payouts. Secondly, Aguenaou et al. [1] conducted their study during the period of 2004-2010; and during this period, in 2008, there was a serious financial crisis due to sub-prime lending that affected global stock markets. These authors did not control for this potential influence. Whereas, in our study, we included companies listed on the Casablanca stock exchange

7 The difference of the samples is explained as follows: the study by Aguenaou et al. [1] regroups all the companies listed on the Casablanca exchange between the years 2004-2010. In our study, we exclude the financial sector and we cover the period of 2011-2013. As for the difference in the measure of the variables of foreign ownership and institutional ownership, Aguenaou et al. [1] used dummy variables to measure the foreign and institutional ownership. In our study we considered the percentage of ownership for the measure of the two variables. 
during the period 2011-2013, in order to avoid the influence of any economic crisis. In addition, as we mentioned earlier, during the 1990s up until the year 2000, the Moroccan government privatized state corporations and promoted these companies to list on the Casablanca stock exchange, increasing the amount of foreign and institutional ownership. Given that Aguenaou et al. [1] studied companies starting in 2004, there could have still been an effect due to this privatization. With our study starting in 2011, we feel confident that any anomaly due to the privatization in Morocco would be negligible.

An additional contribution of our study is the potential to improve policies in emerging countries. Governing bodies in Morocco should promote both foreign companies as well as local companies to increase their holdings in companies listed on the Casablanca stock exchange, which should provide these investors with a higher dividend payout. This, in turn, could help economic activity in this emerging market.

In addition, our results showed a positive and significant relationship between the foreign ownership and the dividend policy. The results are consistent with those of Ullah et al. [30] in the Pakistan context. Moreover, our results are consistent with Cook and Jeon [27] where foreign investors are concerned for foreign investment; they will therefore look to reduce this concern by reclaiming a high level of dividends.

Similar to Norhasniza et al. [22], our results did not show a relationship between the dividend policy and institutional ownership. Interestingly, contrary to Al-Gharaibeh et al. [19] and Manos [28], we were unable to establish a significant relationship between the dividend policy and institutional ownership.

Our research has certain limits. This research was conducted only over a three years period. A longer period might better represent the economic cycle of a company [22]. Also, our analysis did not account for all the sectors of activity, such as the financial sector; and we were unable to control for this sector given the low number of companies by sector of activity $^{8}$. And finally, given the limited number of listed companies on the Casablanca Stock exchange, we are restricted to a small sample size. Accordingly, our results should be interpreted with caution.

Our research provides different avenues of future research, such as a study over a longer period of time with more observations, and one that includes different industries. In addition, it would be interesting to realize this same research in other emerging markets. And lastly, in future research, we suggest using different types of modeling, other than linear regression models, to test the various relationships between dividend policy and capital structure. This would allow an improvement of research methodologies adapted to complex economic realities of listed companies.

8 The majority of industries is represented by 1 to 2 companies in the sample.

\section{REFERENCES}

[1] Aguenaou, S., Farooq, O. and Di, H. (2013). Dividend Policy and Ownership Structure: Evidence from the Casablanca Stock Exchange. GSTF International Journal on Business Review (GBR), 2 (4), 116-121.

[2] Pablo, E. and Gonzalez, M. (2010). Dividend Policy and Ownership Structure in Latin America. Paper presented at the annual meeting of the BALAS Annual Conference, ESADE, Barcelona, Spain.

[3] Albouy, M. (1990). La politique de dividendes des entreprises. Revue d'économie financiére, 12(13), 240-251.

[4] Miller, M.H. and Modigliani, F. (1961). Dividend Policy, Growth, and the Valuation of Shares. The Journal of Business, 34(4), 411-433.

[5] Lintner, J. (1956). Distribution of Incomes of Corporations Among Dividens, Retained Earnings, and Taxes The American Economic Review, 46(2), 97-113.

[6] Lintner, J. (1962). Dividends, Earnings, Leverage, Stock Prices and Supply of Capital to Corporations. The Review of Economics and Statistics, 64, 243-269.

[7] Gordon, M. (1963). Optimal Investment and Financing Policy. Journal of Finance, 18, 264-272.

[8] Litzenberger, R. and Ramaswamy, K. (1979). The effects of Personal taxes and Dividends on Capital Asset Prices: Theory and Empirical Evidence. Journal of Financial Economics, 7(2), 163-195.

[9] Jensen, M. (1986). Agency Costs of Free Cash Flow, Corporate Finance, and Takeovers. American Economic Review, 76(2), 323-326.

[10] Shleifer, A. and Vishny, R. (1986). Large Shareholders and Corporate Control. The Journal of Political Economy, 94(3), 461-488.

[11] LaPorta, R., Lopez, F. and Shleifer, A. (1999). Corporate Ownership Around the Worle. Journal of Finance 54(2), 471-517.

[12] Aivazian, V., Booth, L. and Cleary, S. (2003). Do Emerging Market Firms Follow Different Dividend Policies From U.S. Firms? Journal of Financial Research, 26(3), 371-387.

[13] Allen, F., Bernardo, A. and Welch, I. (2000). A Theory of Dividends Based on Tax Clienteles. The Journal of Finance, 55(6), 2499-2536.

[14] Jain, R. (2007). Institutional and individual investor preferences for dividends and share repurchases, Journal of Economics and Business, 59, 406-429.

[15] Jensen, G., Solberg, D. and Zorn, T. (1992). Simultaneous Determination of Insider Ownership, Debt, and Dividend Policies.

[16] Shleifer, A. and Vishny, R. (1997). A Survey of Corporate Governance. The Journal of Finance, 52(2), 737-783.

[17] Armour J., Deakin S.,Sarkar P. and Singh. S. (2008). Shareholder Protection and Stock Market Development: An Empirical Test of the Legal Origins Hypothesis University of Cambridge, CBR Working Paper; ECGI - Law Working Paper No. 108/2008. 
[18] Thanatawee, Y. (2013). Ownership Structure and Dividend Policy: Evidence from Thailand. International Journal of Economics and Finance, 5(1), 121-132.

[19] Al-Gharaibeh, M., Zurigat, Z. and Al-Harahsheh, K. (2013). The Effect of Ownership Structure on Dividends Policy in Jordanian Companies. Interdisciplinary journal of contemporary research in business, 4(9), 769-796.

[20] Al-Malkawi, H.-A.N., Rafferty, M. and Pillai, R. (2010). Dividend Policy: A Review of Theories and Empirical Evidence. International Bulletin of Business Administration, 9, 171-200.

[21] Rozeff, M. (1982). Geowth, Beta and agency costs as determinants of dividend payout ratios. Journal of Financial Research, 5(3), 249-259.

[22] Norhasniza, M.H.A., Ahmad, Z. and Roslan, S. (2012). The Influence of Ownership Structure on the Firms Dividend Policy Based Lintner Model. International Review of Business Research Papers, 8(6), 71-88.

[23] Easterbrook, F. (1984). Two agency-cost explanations of dividends. American Economic Review, 74, 650-659.

[24] Bozec, Y., Francoeur, C., Labelle, R. et Okoudjou, V. (2010). Investisseurs institutionnels et gouvernance Revue Française de Gouvernance d'Entreprise 7, 83-104.

[25] Harada, K. and Nguyen, P. (2011). Ownership Concentration, Agency Conflicts, and Dividend Policy in Japan. Managerial Finance, 37(4), 362-379.
[26] Demsetz, H. and Lehn, K. (1985). The structure of corporate ownership: Causes and consequences. Journal of Political Economy, 93(6), 1155-1177.

[27] Cook, D.O.and Jeon, Q. (2006). Foreign Ownership, Domestic Ownership, and Payout Policy. Working paper, Department of economics, University of Alabama.

[28] Manos, R. (2002). Dividend policy and agency theory: Evidence on Indian firms. Finance and development research programme, working paper series, 41, 1-25.

[29] Mancinelli, L. and Ozkan, A. (2006). Ownership Structure and Dividend Policy: Evidence from Italian Firms. The European Journal of Finance, 12(3), 265-282.

[30] Ullah, H., Fida, A. and Khan, S. (2012). The Impact of Ownership Structure on Dividend Policy Evidence from Emerging Markets KSE-100 Index Pakistan. International Journal of Business and Social Science 3(9), 298-307.

[31] Chen, Z., Cheung, Y.-L., Stouraitis, A. and Wong, A.W.S. (2005). Ownership concentration, firm performance and dividend policy in Hong Kong. Pacific-Basin Finance Journal, $13,431-449$

[32] Fama, E. et French, K. (2002). Testing Tradeoff and Pecking Order Predictions about Dividends and Debt Review of Financial Studies, 15, 1-33.

[33] Short, H., Zhang, H. and Keasey, K. (2002). The link between dividend policy and institutional ownership. Journal of Corporate Finance 8, 105-122. 